P-ISSN: 2548-5962
$\begin{aligned} & \text { DIRECTORY OF } \\ & \text { OPEN ACCESS } \\ & \text { JOURNALS }\end{aligned}$
httiSSN: 2548-981X

\title{
Strategi Pembedahan di Era Pandemi COVID-19
}

\section{Ni Gusti Ayu Agung Manik Yuniawaty Wetan*, Putu Astri Novianti}

Departemen Ilmu Bedah, Fakultas Kedokteran Universitas Udayana - Rumah Sakit Universitas Udayana, Jimbaran, Bali.

*Penulis korespondensi: manikyw@gmail.com.

\section{DOI: https://doi.org/10.24843/JBN.2020.v04.is01.p03}

Pada akhir 2019, virus corona jenis baru, Severe Acute Respratory Syndrome-Corona virus-2 (SARS-CoV-2) pertama kali muncul di kota Wuhan, China, dan saat ini telah menyebar ke lebih dari 200 negara di dunia sebagai penyakit COVID-19. ${ }^{1}$ Gejala umum penyakit ini yakni demam (44-98\%), batuk (46-82\%), sesak (31\%). ${ }^{2}$ WHO telah menetapkan COVID-19 sebagai pandemi dan angka kasus sudah melewati 1,5 juta kasus di dunia pada awal April dengan angka kematian lebih dari 88 ribu jiwa. ${ }^{1}$

Di Indonesia sendiri, virus ini mulai muncul pada awal Maret dengan jumlah kasus yang kian hari kian meningkat. Tercatat sampai memasuki minggu kedua April, telah terjadi lebih dari 2900 kasus dengan Case Fatality Rate (CFR) atau rasio kematian sebesar $8,07 \% .^{3}$ Rumah sakit tentunya menjadi salah satu zona merah untuk perawatan dan transmisi penyakit ini. Dokter dan paramedis semakin banyak yang terpapar dan menjadi korban.

Pembedahan yang menjadi salah satu layanan dari sistem kesehatan dengan prosedur "emergency" dan "elektive" menjadi aspek penting yang harus diperhatikan. Kamar operasi juga dapat menjadi area berisiko tinggi untuk transmisi infeksi saluran pernapasan. Selain itu, pasien asymtomatic carier yang akan dilakukan pembedahan dapat berpotensi menularkan virus selama masa inkubasi. Suatu penelitian retrospektif di China yang meneliti 34 pasien asimtomatik berusia 34-83 tahun yang dilakukan operasi elektif di awal pandemi, menjadi bergejala COVID-19 pasca operasi dan terkonfirmasi positif setelah dilakukan pemeriksaan laboratorim kuantiantatif RTPCR. Sebanyak $44,1 \%$ pasien membutuhkan perawatan ICU paska operasi dengan mortalitas sebesar 20,5\% karena ARDS (Acute Respiratory Distress Syndrome). Gejala COVID-19 berkembang sangat cepat (rata-rata hari ke- 2-6) paska operasi. Dari penelitian ini disimpulkan bahwa pembedahan mungkin dapat mempercepat dan memperparah progresivitas penyakit ini. Pembedahan tidak hanya menyebabkan gangguan sistem imun, tetapi juga menginduksi respon awal sistem inflamasi. ${ }^{4}$

Menyikapi masa pandemi ini, beberapa asosiasi Bedah dunia menyepakati guideline untuk pembedahan yang dapat diterapkan di tiap negara. Adapun yang menjadi inti dari guideline ini adalah: ${ }^{5}$

1. Pasien akut merupakan prioritas utama. Kemungkinan COVID-19 harus disingkirkan dengan anamnesis riwayat, tes COVID-19, CT toraks (dalam 24 jam terakhir) atau minimal foto toraks.

2. Semua pasien yang direncanakan untuk operasi elektif harus dievaluasi COVID19 dan mendapat persetujuan untuk risiko operasi yang lebih besar. Pertimbangkan stoma dibadingkan anastomosis untuk 
mengurangi perawatan kritis paska standar, maka dapat dipertimbangkan operasi.

3. Penggunaan APD lengkap untuk laparotomi. pemberian antibiotik intravena. ${ }^{6}$ Pada kasus

4. Laparoskopi sebaiknya tidak dikerjakan karena berisiko pembentukan aerosol dan infeksi. Pertimbangkan laparoskopi hanya pada kasus individu tertentu dimana keuntungan klinis kepada pasien lebih besar dari risiko transmisi virus.

5. Dalam ruang operasi hendaknya jumlah staf dibatasi dan menggunakan APD lengkap. Evakuasi asap diatermi / sumber energi lain.

6. Situasi risiko pembedahan termasuk penggunaan pelindung mata pada pasien batuk ataupun pemasangan NGT sebagai salah satu prosedur yang berisiko. Hanya endoskopi emergensi yang dapat dilakukan. Prosedur Upper Gastrointestinal memiliki risiko tinggi aerosolisasi dan wajib menggunakan APD lengkap.

American College of Surgeons juga mengeluarkan guideline yang berisi pertimbangan untuk kasus-kasus spesifik seperti hemoroid trombosis akut yang disarankan untuk non-operatif bila memungkinkan atau pembedahan rawat jalan dengan lokal anestesi. Pembedahan emergensi dapat dilakukan untuk perdarahan aktif atau stadium yang lebih parah. Kasus apendisitis akut tanpa komplikasi disarankan dengan trial antibiotik intravena terlebih dahulu. Pasien dengan kolelitiasis dan kolesistitis kronik disarankan untuk pemberian anti nyeri dan penundaan operasi. Jika harus dilakukan operasi, dapat dipertimbangkan laparoskopi kolesistektomi untuk meminimalisir "hospital stay" Untuk kasus kolesistitis akut lebih disarankan tindakan per-laparoskopi. Namun, jika pasien berisiko tinggi atau ruang operasi tidak sesuai tertentu dapat dikondisikan dengan pertimbangan yang reasonable seperti biopsi tumor mama yang merupakan kasuk elektif tapi prosedur ini tidak dapat ditunda. ${ }^{7}$

Di Indonesia sendiri, Persatuan Dokter Spesialis Bedah Umum Indonesia (PABI) juga telah mengeluarkan pedoman kerja bagi seluruh anggota PABI di Indonesia dalam melaksanakan pelayanan bedah diantaranya pembatasan kunjungan ke poliklinik bedah, penundaan operasi seperti hernia tanpa komplikasi, apendisitis kronik, luka diabetes tanpa komplikasi sistemik, tumor jinak, tumor ganas risiko rendah, dan struma nodosa non toksik / tanpa terapi hormonal. Sedangkan untuk kasus kegawatdaruratan bedah tetap dilayani di IGD sebagai kasus emergensi seperti pasien dengan kondisi mengalami luka dengan perdarahan yang banyak, nyeri perut yang semakin memberat, hernia yang disertai nyeri atau tidak bisa BAB / flatus / muntah, tidak bisa BAK, tidak bisa BAB / flatus, perdarahan saluran cerna akut, dan benda asing di tubuh. ${ }^{8}$

Sebelum dilakukan pembedahan, penting dilakukan penilaian pre-operatif yang bertujuan untuk mengidentifikasi pasien berisiko tinggi dan menyesuaikan prosedurnya. Untuk pasien yang teridentifikasi positif COVID-19, harus mengoptimalkan kondisi respirasi pasien mulai dari patensi airway, kebutuhan oksigen, perubahan foto rontgen dada, dan analisis gas darah. Perlu juga dilihat adakah kegagalan organ, tanda-tanda syok, gagal hati ataupun gagal ginjal. Pertimbangkan pembedahan yang dapat mengurangi paparan petugas dan memperpendek durasi operasi. ${ }^{9}$

Salah satu contoh rekomendasi, jika operasi urgent / emergensi dengan gejala klinis pneumonia yang jelas atau rapid test (+), pasien diperlakukan PDP dengan 
penggunaan APD level 3. Namun pasien jika tanpa gejala pneumonia yang jelas dan rapid test (-), operasi dijalankan dengan APD level 2 dan anestesi regional jika memungkinkan. APD level 2 terdiri atas APD level 1 (baju khusus kerja, masker bedah 3 ply, gloves, head cap) ditambah dengan masker N95, pelindung mata, surgical cap, dan gown. APD level 3 yakni APD level 2 ditambah face shields, apron, gown coverall,double/triple gloves, dan boots. Berkaca dari penelitian retrospektif di Wuhan, mungkin dapat dipertimbangkan untuk mengisolasi pasien selama 14 hari sebelum operasi elektif dilakukan untuk menyingkirkan kemungkinan COVID-19.

Selain pedoman kerja, sangat perlu untuk memperhatikan kelayakan ruang operasi. Sirkulasi udara di ruang operasi menjadi perhatian krusial guna meminimalisir risiko infeksi. Negara seperti Singapura telah mendesain ruang operasinya dengan memiliki area bertekanan negatif yang di desain untuk pasien dengan terkonfirmasi (atau kecurigaan) COVID-19. Ruang/ koridor penerimaan (anteroom) dan ruang induksi anestesi memiliki atmosfer tekanan negatif. Sedangkan kamar operasi, ruang persiapan dan ruang scrub memiliki atmosfer bertekanan positif. ${ }^{10}$

Di Bali sendiri, Pemerintah daerah propinsi Bali telah menunjuk Rumah Sakit Universitas Udayana Jimbaran sebagai rumah sakit khusus rujukan COVID-19.11 Pembatasan pasien poliklinik telah dilakukan. Dokter residen turut diperbantukan. Pembedahan yang bersifat elective sementara ditunda, dan pembedahan emergensi dengan kasus COVID-19 tentunya hanya bisa dilakukan dengan memenuhi standar penanganan pasien dengan COVID-19 terutama di kamar operasi.

Sebagai simpulan, dengan memperjelas strategi pembedahan dan mengikuti protokol pembedahan yang telah disepakati, akan membantu memberikan pelayanan yang terbaik kepada pasien sekaligus melindungi petugas medis di era pandemi COVID-19 ini.

\section{DAFTAR PUSTAKA}

1. World Health Organization. Coronavirus disease 2019 (COVID-19) Situation Report - 70. World Health Organization [serial online]. 30 Maret 2020 [diakses 31 Maret 2020]. Diunduh dari: https://www.who.int/docs/defaultsource/coronaviruse/situationreports/20200330-sitrep-70-covid19.pdf?sfvrsn=7e0fe3f8_2.

2. Auwaerter PG. Coronavirus COVID-19 (SARS-CoV-2). John Hopkins ABX Guide [serial online] 8 April 2020. [diakses 8 April 2020]. Diunduh dari: https://www.hopkinsguides.com/hopkins/ view/Johns_Hopkins_ABX_Guide/54074 7/all/Coronavirus_COVID_19_SARS_C oV_2_.

3. Kompas. Data COVID-19 di Indonesia. Kompas.com [serial online] 9 April 2020 [diakses 9 April 2020]. Diunduh dari: https://www.kompas.com/covid-19.

4. Lei S, Jiang F, Su W, dkk. Clinical characteristics and outcomes of patients undergoing surgeries during the incubation period of COVID-19 infection. EClinicalMedicine. 2020.

5. Royal College of Surgeon. Update Intercollegiate General Surgery Guidance on COVID-19. Association of Coloproctology of Great Britain and Ireland [serial online] 25 Maret 2020 [diakses 8 April 2020]. Diunduh dari: https://www.acpgbi.org.uk/content/upload s/2020/03/Updated-IntercollegiateGeneral-Surgery-Guidance-on-COVID19-final-with-logos13-1.pdf.

6. American College of Surgeons. COVID19 Guidelines Triage of Emergency General Surgery Patients. American 
College of Surgeons. [serial online] 25 Maret 2020 [diakses 8 April 2020]. Diunduh dari: https://www.facs.org/covid-19/clinicalguidance/elective-case/emergencysurgery.

7. Brindle M, Gawande A. Managing COVID-19 in Surgical System. Ann Surg. 2020.

8. Persatuan Ahli Bedah Indonesia. Surat Nomor 30/PP-PABI/III/2020 Pelayanan Bedah Pada Era Pandemi COVID-19 tanggal 21 Maret 2020. Jakarta: Persatuan Ahli Bedah Indonesia; 2020.

9. Tang G, Chan AKM. Perioperative management of suspected / confirmed cases of COVID-19. Anaestesia Tutorial of the Week. [serial online] 6 April 2020 [diakses 8 April 2020]. Diunduh dari: https://www.wfsahq.org/components/com _virtual_library/media/1c4ec5c64b9aaacf 7c47f76a61fb6edc-atow-422-01.pdf.

10. Ti LK, Ang LS, Foong TW, Ng BSW. What we do when a COVID-19 patient needs an operaton: operating room preparation and guidance. Can J Anesth. 2020.

11. Gubernur Bali. Surat Keputusan Gubernur Bali nomor 271/03-B/HK/2020 tentang penunjukan RSPTN UNUD sebagai RS Khusus Isolasi COVID-19 tertanggal 31 Maret 2020. Denpasar: Gubernur Bali; 2020. 